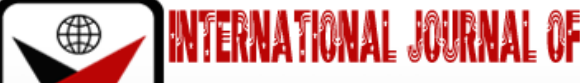

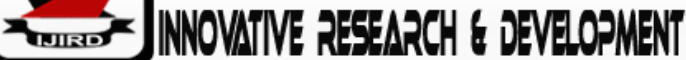

ISSN 2278-0211 (Online)

\section{Exploring the Roles of Language as a Panacea for Contemporary Socio-economic Challenges in Nigeria}

\author{
Taofeek Olanrewaju Alabi \\ Senior Lecturer, Department of General Studies, \\ Federal Polytechnic, Ado-Ekiti, Nigeria
}

\begin{abstract}
:
This paper examines how English language can be used to overcome the contemporary socio-economic challenges in Nigeria considering the pivotal roles in the functioning of the Nigerian society. Using the theoretical view of Stubbs, the paper discusses the functions of language in human society before examining the functions of English language in Nigeria against the indigenous languages. It $x$-rays the contemporary socio-economic challenges facing the country and observes that the English language is better positioned as the language of overcoming the nation's socio-economic challenges. However, low proficiency level in its use by Nigeria's second language (L2) users is a major bane in this quest. To overcome this deficiency, the paper recommends among others, a paradigm shift in the method of teaching English language in our schools from rote learning of the linguistic rules to that of improving learner's overall communicative abilities in the four skills of English language and a task-based instruction (TBI) method in Nigerian schools.
\end{abstract}

Keywords: Indigenous languages, contemporary socio-economic challenges, second language (L2) users, linguistic rules, communicative competence

\section{Introduction}

If there is any activity that human beings perform every day, it is the use of language to communicate. As a matter of fact, many of man's means of living are intricately connected to the use of language. Language has many definitions. Dada (2004:2) defines it as 'an arbitrary vocal system of communication used among members of a speech community while Osisanwo (2003) defines it as 'human vocal noise or the graphic representation of the noise, used systematically and conventionally by members of a speech community for purposes of communication'. Essentially, language is a set of contextual codes intelligible and meaningful to those who share the codes. The basic function of language is communication. Professionals and artisans all deploy language to perform or enhance their occupations and status. Adedun (2014) asserts that 'human activities are diverse and complex, and all involve a system of meaning making through language'. Through language, people are able to live and work together, pursue individual and societal goals, settle conflicts, design socio-economic and political plans that would cater for the present and the future.

Furthermore, Obuh and Omenogor (2012) opine that language as an instrument of communication may be used 'to influence personality, to declare war, to oppose ideas, intentions and actions; to scatter, to condemn and generate violence. It could also be used to entertain, inspire, educate, establish cordial relationship, settle disputes and make peace with people or communities. Language must be seen as a vehicle of communicating the intended meaning for achieving set goals, and not an end in itself. These set goals in this case, would be education, national unity and/or identity, and socioeconomic development.

The English language has been in use in Nigeria for over five centuries after the colonial administration. The prominent roles it has played before and after Nigeria gained her independence has allowed it to be preeminently established virtually in all communicative domains of national life. The English language has served as a key instrument and foundation for many socio-economic and political activities in the country, as against all other languages within Nigeria's linguistic environment. Many Nigerians are desperately trying to learn English-not simply for selfimprovement, but as an economic necessity which will help them tap into new opportunities at home and abroad.

However, in an effort to find lasting solutions to the country's socio-economic challenges, less attention has been paid to the roles of language, especially the English language despite the numerous roles it performs in Nigeria. Owolabi (2016:135) asserts that 'as vital as language is to human existence, little or no attention is accorded it by national development planners.' This underscores the relevance of this paper.

\section{Theoretical Issues on Functions of Language}

Theories in linguistics have different conceptions about language ranging from the purely formalist approach, which places emphasis on discovering some of the abstract principles that lie at the very core of language to theories that 
consider language in relation to its use in the society. This work aligns with the latter theories. A large corpus of literature exists on the functions of language in human society (e.g. Jakobson, 1960; Hymes 1962; Halliday, 1970; Brown and Yule 1983). This study, however, relies on Stubbs's (1995) classifications of functions of language as the theory encompasses some other linguists' views.

Stubbs (1995) built on the earlier propositions of Jakobson (1960) and Hymes (1962), to propose seven functions of language. The functions include (1) expressive/ emotive function (2) directive/ conative or persuasive function (3) poetic function (4) contact function (5) metalinguistic function (6) referential function, and (7) contextual/ situational function. Osisanwo (2003) explains that the expressive function occurs when language is used to express the inner state of mind of the speaker. It may be an instantaneous reaction to an ongoing event e.g. hurrah! It's a goal! The directive or conative or persuasive function of language allows the speaker to direct the hearer to carry out an action. It may also be used to persuade or plead with the hearer for an action to take place or not. The poetic function of language allows language users to use it creatively for aesthetic purposes while the contact function of language, also regarded as 'phatic' function allows people to use language for brief social or psychological interaction e.g. for greetings or in an attempt to open a channel for communication. The metalingual function is performed when language draws attention to itself for the purpose of clarification on any of its levels. The referential function ensures that the denotative meaning of a word or expression is the physical object which the language user has used it for, while the contextual/ situational function of language allows language user to relate his experience to others with regard to the immediate environment.

The contextual/ situational function of language is very relevant to this study as it allows language users to employ language in solving contextual and situational problems of immediate environment which may be political, educational, socio-economic, etc. In this sense, the acquisition of language is of particular importance for the process of communication, humanization, socialization and societal development. Having established the importance of language to man, we shall now discuss the language situation in Nigeria vis-a-vis the English language and the indigenous languages.

\section{Language Situation in Nigeria}

Nigeria is a multi-lingual, multi-ethnic and culturally pluralistic nation. Nigeria's sociolinguistic reality has made bilingualism and multilingualism obligatory at both the individual and societal levels. The multiplicity is as a result of coming together of diverse ethno-linguistic and cultural groups with various languages to form a nation. In addition to this, English and other foreign languages such as French, Arabic and Portuguese were also introduced. Even though the exact number of languages in Nigeria is still subject to debate, many scholars have opined that there are more than 400 languages belonging to different ethnic-linguistic groups in the country (e.g. Bamgbose, 1995; Essien, 2005; Agbedo, 2005). Eno-Abasi (2003:135) sums up the contending numbers by stating that "we cannot promptly specify the number of languages spoken in Nigeria" as a nation. However, the obvious fact is the dominance of English over every other language within the polity.

Historically, the seed of English spread was planted in foreign lands and climes by the English themselves in their quest for colonial territories and trade. The British Colonial administration introduced and institutionalized English as the Nigerian official language as contained in the education ordinances of 1882, 1896, 1916 and the introduction of certification system in the country's educational system between 1882 and 1926. The English language is well received among Nigerians and it is still the most widely spoken language in both metropolitan and cosmopolitan cities in Nigeria. This premised Bamgbose's (1971:102) assertion that 'Of all the heritage left behind in Nigeria by the British at the end of colonial administration, probably none is more important than the English language'.

Since independence, the Nigerian linguistic situation has encouraged the English language to thrive as no indigenous language and its speakers want to be subservient to the other and the identification of Hausa, Igbo and Yoruba as the three major indigenous languages has not helped the situation. It has further heightened fear and suspicion among members of the minority ethnic groups in the country; the fear of being politically dominated, economically marginalized and culturally belittled (Babajide, 2001:10). This apart, none of the three major indigenous languages could be used as a national language; a language that unites the whole Nigerians. In the view of Nida and Wonderly (1971) as cited in Olasehinde (2017):

In Nigeria, there is simply no politically neutral language. In fact,

the division into three major regions reflects the three language

poles: Hausa, Yoruba and Igbo. The political survival of Nigeria

as a country would even be more seriously threatened that it is

if any of these languages were promoted by the Government as

being the one national language.

In view of this rivalry, English language continues to exploit the situation as it readily plays the roles of lingua franca as well as that of the official language.

The English language enjoys positive attitudes and overwhelming acceptance from Nigerians and has taken firm roots in the Nigerian speech community. According to Afolayan (2001:83) asserts that:

As ex-colonial people, Nigerians hold English in great awe.

They so overrate English that literacy in English is considered

the only mark of being an educated person... Indeed, some

Nigerians, desirous of having a headstart in the drive for literacy with its attendant politico-socio-economic advantages

are already striving to make it their mother tongue. 
As a result of the above, the English language performs multiplicity of functions in Nigeria as it is called to duty in nearly all communicative situations. It is the language of education, the language of national politics and government, banking, commerce, of mass media, of most written communication and a virile literature (Adetugbo, 1987:165). Being the official language and that of government administration, English serves as the language of recording official meetings. It is also the language used in letters, memoranda, circulars, protocols and diplomacy. It is the language of civil servants, election campaigns and political debates in the country. It equally functions as language of commerce, where negotiations, advertisements, contract and agreement wordings are encoded with it. It is the language of boardroom interactions, annual general meeting of stakeholders, and the Nigerian Stock Exchange means of business transactions.

The English language has dominated the educational system at the expense of other languages. It has not only functions as a compulsory subject in the curricular of primary, secondary and tertiary education, but also as the official medium of instruction in all levels of education. As a matter of fact, English is also used as the language of educational evaluation (Awonusi, 2004:70). Students are tested in English and the Use of English in most examinations conducted in the country (i.e. JSCE, SSCE, NECO and JAMB). A credit pass in English is required for admission to tertiary institutions, while written and oral job interviews are conducted in English.

English is equally the language of law as legal businesses in courts and tribunals are done and documented in it. These include: affidavits, wills, certificate of occupancy, tenancy agreements, mortgage agreements and oaths are written and sworn to in English. Even the Nigeria's constitution is carved with it, so also are decrees, bills, edicts and bye laws of states and local governments are written in it.

The globalization relevance of English is another factor adduced for the overwhelming acceptance and use in Nigeria. That the English language has virtually become a world language cannot be denied. According to Graddol (1997) as cited in Akere (2009), 'The English language is the most widely spoken language in the world. It is a language used in about 673 countries globally'. Today, the global outreach of English as a world language made it to supplant local languages in the former colonial territories. That is why in Nigeria's second language (L2) environment, speakers of English are daily increasing. According to Otagburuagu (2015:13):

It is estimated that Nigeria has four (4) million native speakers of

English which places her on the $5^{\text {th }}$ position after Australia in the

Global English language native speaker ranking profile of 2012.

Again, it is estimated that over 79 million Nigerians use the English

language as the second language-a number that makes her come

first in the West African English language speech community

The instrumental relevance of English is another factor motivating positive attitudes towards it. This shows that for economic stability, social relevance and political participation at local, state, national and international levels, ability to communicate in English is vital. It is also the language of science and technology. For technological importation and development, the English language is important.

The constitutional provisions on language, as well as the provisions in the National Policy on Education (NPE) equally favour the dominance of English. The National Policy on Education (NPE, revised 2004) subjected the use of mother tongue to early child education while the English language is reserved for learning and teaching from upper primary school to the tertiary level of education. The 1999 Constitution of the Federal Republic of Nigeria also has some pro-English and anti-indigenous languages provisions as enumerated below:

The business of the national assembly shall be conducted in English

and in Hausa, Igbo and Yoruba when adequate arrangements have

been made therefore.

The same thing goes for the state House of Assembly as contained in Section 97 that:

The business of the house of assembly shall be conducted in English,

but the house may in addition to English conduct the business of the

house in one or more other languages spoken in the state as the house

may by resolution approve

The National Policy on Education (NPE, 2004) also contains the following language provisions. Section 4, paragraph 15 states that:

Government will see to it that the medium of instruction in the primary

School is initially the mother tongue or the language of the immediate

community, and at a later stage, English

The language component of the Junior Secondary Curriculum reads thus:

In selecting the Nigerian languages, students should study the

Language of their own area in addition to any of the three mains

Nigerian Languages, Hausa, Igbo and Yoruba subject to availability

of teachers.

The underlined expressions above indicate government's unwillingness to improve the status and use of indigenous languages. Even, the Constitution provisions which recognize Hausa, Igbo and Yoruba as three major indigenous languages for national use, gives them subservient roles to English in the country.

Recently, Ayoola (2016: 88) claims that 'In contemporary Nigeria, the English language has already encroached into and it is still steadily entrenching itself in domains that used to be exclusive preserve of indigenous languages.' Some of the observed practices include:

- The use of English for formal, semiformal and informal occasions by officials at the three tiers of government 
(local, state and federal).

- The displacement of the mother tongue by English as the medium of instruction in pre-school and the first three years of primary education in Nigerian Nursery and Primary school. Thus, rendering the constitutional provision irrelevant (italicized ours).

- The relegation of indigenous languages (including Pidgin English) as the language of artisans, unskilled labour, and other categories of have-nots in the society.

- The use of English instead of indigenous languages during formal occasions by the perceived custodians of culture exemplified by local council chairpersons and secretaries, chiefs, emirs, obas and obis.

- $\quad$ The near exclusive use of English for mass media, internet surfing, social networking, leisure reading and writing and other socio-cultural activities by the new generation of Nigerians.

Some scholars have criticized the preferred use of English to the indigenous languages in nearly all communicative domains in Nigeria (i.e. Adegbite, 2010; Ayoola, 2016; Asiyanbola, 2016). They assert that despite the historical coincidence and national need that brought about the prevalent use of English in Nigeria, proficiency in it for the majority of those in our formal education system is very poor (Baker 2001; Dada 2006; Fafunwa, 1982; Jibril, 2007; Akere,1995; Adesanoye, 1994 and 2004). Adegbite (2009: 75) notes that despite the high status accorded English language in Nigeria, competent speakers of the language remain very few. They range between 5-10\%. Records of poor performances and usage are given at all levels of education and strata of communication in the society. According to Banjo (2014:2):

Perhaps for too long we have looked on helplessly as the

spoken and written English of recent products of Nigerian education at all tiers has become an embarrassment to the system and a source of frustration to would-be employers in the private and public sectors of the economy of our country

Furthermore, Bamgbose (2006) argues that if English as a medium produced the best results and children were able to master it as well as other subjects taught through it very well, there would not have been any concern. The reality, of course, is that at virtually all levels of education, performance in English is inadequate and this continues to affect acquisition of knowledge in other subjects. The failure to attain proficiency in English in our educational institutions is thus transferred into the society.

Despite their criticisms, it is clear from the foregoing that nearly all facets of life in Nigeria requires the use of English language, and as such puts the language in a vantage position as the lubricant for socio-economic advancement in the nation. The question now is how to invest more in the teaching and learning of English since the ability to use it effectively as communicative situations demand is a prerequisite to overcoming socio-economic challenges in our society. What then are the socio-economic challenges facing the country?

\section{Socio-Economic Challenges}

In order to understand the concepts of socio-economic challenges, let us begin by explaining the concept of socioeconomic development. The New Partnership for Africa's Development (NEPAD) declaration of 2010 regards socioeconomic development as the relationship between economic activity and social life. It is the improvement of people's lifestyles through access to quality education, skills development and employment, improved incomes, better healthcare, decent housing, safe drinking water and good sanitation, as well as equitable distribution of a nation's wealth. Socioeconomic development is an integral part and a major determinant of national development, which is the ultimate goal of individual efforts and national aspirations.

Socio-economic development is measured with indicators, such as gross domestic product (GDP), life expectancy, literacy and levels of employment. The impacts of socio-economic development are seen in changes in laws, changes in the physical environment and ecological changes. Therefore, the socio-economic objectives according to The New Partnership for Africa's Development (2010) are to:

- $\quad$ promote self-reliance in development and build capacity for self-sustaining development

- accelerate socio-economic development to achieve sustainable development and poverty eradication

- $\quad$ strengthen policies, delivery mechanism and outcomes in key social areas including education, combating of HIV and AIDS, and other communicable diseases

- $\quad$ ensure affordable access to water, sanitation, energy, finance (including micro-finance), markets, ICT, shelter and land to all citizens, especially the rural poor

- $\quad$ progress towards gender equality in all critical areas of concern including equal access to education for girls at all levels

- $\quad$ encourage broad based participation in national development by all stakeholders.

On the contrary, when the opposite of the above development indices exists in a society, such society suffers from socio-economic challenges. To a large extent, this seems to be the situation in Nigerian at the moment where many wallow in abject poverty; where majority of the citizens within working ages are unemployed, where many could not afford three daily square meals, where access to good roads, pipe- borne water, electricity supply and good health care facilitiesare epileptically provided or completely not available; where the country's educational sector is lamentably in a depressed state. These socio- economic problems mount in the face of state corruption and government ineptitude. 


\section{The English Language and Social Economic Development}

Language and socio-economic development are interwoven phenomena. Both are situated and achieved within human society. It is predictable that once a nation overcomes linguistic challenges, national development is imminent. Economically speaking, billions of people around the globe are desperately trying to learn English-not simply for selfimprovement, but as an economic necessity. In Nigeria, and other English-speaking countries all over the world, one of the many motivating factors for learning English is to secure well-paid jobs within the most dynamic organizations and industry. Thus, competency in English is a necessary prerequisite for employment or hiring a new employee which eventually improves an individual's economic conditions.

In an attempt for Nigeria to overcome heavy reliance on only white-collar jobs, combat poverty and wide spread unemployment, much emphasis is now placed on entrepreneurship. The skill is taught in all tertiary institutions in the country, and it appears to attract foreign direct investment (FDI) from English speaking developed nations. There is no doubt that good communication skills in English is therefore a valuable asset that enables the entrepreneur establish and disseminate the goals of his enterprise, develop plans and organize human and other resources in the most effective and efficient way. In fact, the economic security of most entrepreneurs depends on their negotiating and marketing skills in English both at local and international levels. Also, research shows a direct correlation between the English skills of a population and the economic performance of the country. Indicators like gross national income (GNI) and GDP go up(EF English Proficiency Index,2018).

The English language is mostly the preferred language of science and technology. Since technology is a means to extend man's reach, then it is necessarily connected to language. Science and technology are imported, imparted and operated in English. The language empowers people to apply knowledge gained from science and technology to better their lot and the society. Moreso, in the world of information and communication technology (ICT) which has a pervasive influence on education delivery, the English language dominates. ICT, through television, radio and satellite communication, on-line services, e-mail, computer teleconferencing, has brought the world to the doorstep of the youths and other computer literate people. Consequently, for many of the growing numbers of internet users worldwide, the English language is not viewed as a useful tool of communication between people of varying backgrounds in a variety of communicative contexts (Mckay, 2000:5). Any individual or nation that wants to excel in this area of ICT must use English effectively.

Furthermore, the English language epitomizes professional competence in Nigeria. Consequently, aspiring professionals are quick to recognize it as the language of intellectual and academic discourse. Sometimes, articles are rejected by professional journals because of 'poor' English. Lack of competence in the language becomes an obstacle for those who aspire to garner attention for new products or ideas in the world of scholarship, scientific research, or business. Essen (1998:113) collaborates this when he claims that 98\% of all physicists in Germany strive to be proficient in English as they use it as their working language.

As globalization becomes a dominant feature of post-modern industrial society, no country in a globalized world can afford to remain in isolation. The English language is the vehicle of global participation and development. According to Crystal (1997), Peters (2004) and Graddol (2006), about 80 per cent of the world's trade and financial business is transacted in the English language. Perhaps, the more convincing macroeconomic level benefit would be the potentially higher level of remittances from those countries with significant numbers of migrants with improved English skills. With a common trend of migration, skilled workers lose out on a better income opportunity due to their limited knowledge of English and poor communication skills in it. Hence, enterprises worldwide have noted the necessity of having a workforce that is able to communicate in English (Mckay2002).

From the foregoing, it is obvious that effective use of English language goes along with socio-economic development not only in Nigeria but in most English-speaking countries of the world.

\section{Conclusion}

In the fight against socio-economic challenges in Nigeria, the importance of English language as panacea cannot be overemphasized. However, the investment in the quality of teaching and learning of the language needs to be handled properly so as to provide the opportunity for millions of Nigerians to excel in their different professional fields both locally and internationally. The low proficiency level in English by second language users in Nigeria must be tackled head on for the attainment of communicative competence in the four basic skills of English. This should be the goal of teaching and learning of the language, which will eventually serve as catalyst for socio-economic opportunities and breakthrough. It is in line with these objectives that the paper makes the following recommendations.

\section{Recommendations}

Curriculums in the schools should be re-designed to emphasize communicative competence which encourages integrated language teaching methodology where the four skills of English language are adequately taught. This approach shifts from memorizing theories and inculcation of formal and structural rules of language to that of performance. In this case, English language teaching is practically oriented and functionally imparted as concentration is on better performance in English in all contexts rather than limiting it to just a classroom subject.

The above requires the language teacher to employ a predominantly communicative, task-based, learner centered approach in teaching English language whereby different contexts are created in the classroom setting for practical English language use. The task-based instruction (TBI) approach may be relevant here. This method uses tasks or standaline activities which require comprehending, producing, manipulating or interacting in the target language. It helps learners explore the multitude of communication opportunities provided in their surroundings by: 
- Knowing how to use language for a range of different purposes and functions.

- Knowing how to vary our use of language according to the setting and the participants (e.g. knowing when to use formal and informal speech or when to use language appropriately for written as opposed to spoken communication)

- Knowing how to produce and understand different types of texts (e.g., narratives, reports, interviews, conversations)

- Knowing how to maintain communication despite having limitations in one's language knowledge (e.g., through using different kinds of communication strategies).

- Use of authentic (non-pedagogic) texts and communication activities linked to 'real-world' contexts, often emphasizing links across written and spoken modes and channels.

To achieve (a-e) above, adequate and appropriate instructional materials should also be provided in schools for effective teaching of English language skills. Technological developments have resulted to inventions of different teaching aids. To teach these basic communicative skills of English especially listening and speaking will require provision of a wellequipped laboratory. Audio- visual equipment should be provided to facilitate teaching and learning of English in a second language environment.

English Language teachers should also embark on regular training to update their teaching knowledge and enhance efficiency. A situation where a teacher is stuck to outdated teaching method in teaching of English will not enhance development of communicative language skills in learners.

There is need for establishment of more adult literacy centres for learning of English language with transactional and interactional motives.

Further research and development of standard Nigerian English (SNE):-

\section{References}

i. Adedun, E.A. (2014) English in National Development. In Adedun, E.A and Sekyi-Baidoo, Y.(Eds) English studies in focus: Readings in language and literature. Faculty of Languages,

ii. University of Education, Winneba, Ghana. Pp. 2-7.

iii. Adegbite, W. (2009) The psycholinguistics of English language in Nigeria. Ibadan: KraftBooks Limited.

iv. Adegbite, W. (2010) English language usage, uses and misuse(s) in a non-host second language context, Nigeria. Inaugural lecture series 231. Ile-ife: Obafemi Awolowo University Press.

v. Adesanoye, F. (1994) Tertiary English in Nigeria. In Asein, S.O. and Adesanoye, F. A. (Eds.) Language and Polity: Essays on Language and Society in Africa. Ibadan: Sam Bookman, Pp132-47.

vi. Adesanoye, F (2004) The English Language in Nigeria: The case of a vanishing model. In Owolabi, K. and Dasylva, A. (Eds) Forms and functions of English and Indigenous languages in Nigeria: Some critical perspectives. Ibadan: Group Publishers.

vii. Adetugbo, A. (1987) Nigerian English Phonology: Is there a standard? Lagos Review in English Studies: A Journal of Modern languages.

viii. Afolayan, A (1994) Valendictory lecture: language as a neglected factor of development in Africa. In Adegbite, W. and Onukaogu, C.E. (Eds) Language in education in Nigeria: some critical perspectives. Ile-Ife: Centre for Language in Education Development (CELED).250-258

ix. Agbedo, C.U (2005) Communicative inequity in a participatory democracy: The linguistic imperatives.

x. The International Journal of Communication, (3) 1.17-35.Ijoc.org/index.php/ijoc/index. Retrieved July 23, 2019.

xi. Akere, F. (1995) Languages in the curriculum: An assessment of the roleof English and other languages in education delivery process in Nigeria'. In Bangbose, A., Banjo, A. \& Thomas, (Eds)New Englishes:A West African Perspective. Ibadan: Mosuro Publisher. 178-199.

xii. Asiyanbola, A.A (2016) The roles of the mother tongue and the second language in thesocio- politicaland economic development of Nigeria. In Odebunmi, A andAyoola, K.A (Eds)Language, context and society. Ile-Ife: Obafemi AwolowoPress. 112-127.

xiii. Awonusi, V.O. (2004) 'Globalization and Hegemonic English in Nigeria: Identity Conflicts and Linguistic Pluralism'. In Duro Oni et al (Eds) Nigeria and Globalization: Discourse on

xiv. Identity, Politics and Social Conflict. Lagos: CBAAC. Pp 85-102.

xv. Ayoola, K.A. (2016) Linguistic human rights domination, memorization and linguicism in the language of governance and education in Nigeria. In Odebunmi, A andAyoola, K.A. (Eds) Language, context and society. Ile-Ife: Obafemi Awolowo Press. 112-127.

xvi. Babajide, A.O. (2001) Language Attitude Patterns of Nigerians. In Igboasnusi (Ed) Language attitude and language conflict in West Africa. Ibadan: Enicrownfit Publishers.

xvii. Baker, C. (2001) Foundation of bilingual bducation and Bilingualism. Clevedon: Multilingual Matters.

xviii. Bamgbose, A. (1995) English in the Nigerian Environment'. In Bamigbose (Eds) New Englishes: A West African perspective, Ibadan: Mosuro Publishers.

xix. Bamgbose, A. (2006) 'Linguistics and Social Responsibility: The Challenges for the Nigerian Linguist'. A keynote Address delivered at the $20^{\text {th }}$ Annual Conference of Linguistic Association of Nigeria, Abuja, Nigeria.

xx. Banjo, A. (2014). The deteriorating use of English in Nigeria. In Akinjobi, A (Ed) English language clinic lecture series 1-5, Vol. 1. Ibadan: Edunjobi Enterprises. Pp 2-13.

xxi. Brown, G and Yule, G. (1983) Discourse analysis. Cambridge: Cambridge University Press.

xxii. Crystal, D. (1997) English as a global language. Cambridge: CUP. 
xxiii. Dada, S.A. (2006) Language Contact and Language Conflict: The Case of Yoruba English Bilinguals. In Ndimele, O., Ikekeonwu, C. and Mbah, B. M. (Eds) Language and Economic Reforms in Nigeria. Port-Harcourt: M\&J Grand Orbit Ltd.68-85.

xxiv. EF English Proficiency Indexhttps://www.ef.com/wwen/epi/. Assessed August 16, 2019.

xxv. Eno-Abasi, E.U. (2003) Tonal Reconstruction in Eastern Lower Cross Lects. In Ndimele, O. M. (Ed.) Four decades in the study of languages and linguistics in Nigeria: A Festschrift for Kay Willaimson. Aba: National Institute for Nigerian Languages.

xxvi. Essen, A. J. V. (1998). The Rise and Role of English as an International Language: Some Educational Consequences. Humanizing Language Teaching. Year6, Issue 4; November 04 (www.hltmag.co.uk/nov04/mart02.htm).Assessed July 23, 2019.

xxvii. Essien, O (2005) National Development, Language and Language Policy in Nigeria. In Essien, O. and Okon. M. (Eds) Topical Issues Sociolinguistics: The Nigerian perspectives. Port Harcourt: Printing and Publishing Co.

xxviii. Fafunwa, A.B. (1982) An integrated primary school curriculum scheme in Nigeria: A six-year project In Afolayan, A. (Ed). Yoruba language and literature. Ibadan: University Press Ltd.

xxix. Federal Republic of Nigeria (1999) Constitution of the Federal Republic of Nigeria. Lagos: Federal Government Press.

xxx. Federal Republic of Nigeria $(1998,2004)$ National Policy on Education (Revised Edition).Lagos: Federal Government Press.

xxxi. Graddol, D. (2008) English Next: 'Why global English may mean that HB the end of English as a foreign language.' ULIS.

xxxii. Halliday, M.A.K (1970) Language structure and language function. In Lyons, J (Ed) New Horizons in linguistics. Harmondsworth. Penguin Books. 140 - 165.

xxxiii. Hymes, D (1962) The ethnography of speaking. In Gladwin, T. and Sturtevant, W. C. (Eds) Anthropology and human behavior. Washington, D.C.: Anthropology Society of Washington.

xxxiv. Jakobson, R. (1960) Closing statements: Linguistics and poetics. In Sabeok, T. (Ed) Stylein language. New York: The Technology Press of MIT.

xxxv. McKay, S.L. (2002) Teaching English as an international language: Rethinking goals and approaches. Oxford: OUP.

xxxvi. NEPAD (2001) New Partnership for Africa's Development (NEPAD) October 2001. www.nepad.org/system/files/NEPAD\%20Framework\%20(English).pdf.Assessed July 23, 2019.

xxxvii. Obuh, E.I. and Omenogor, H.D. (2012) Language and communications as instrument of conflict resolution in Nigeria. NATECEP Journal of English and Communication Studies. 8: 69-76

xxxviii. Olasehinde, M.O. (2017) 'Effective communication in English for higher education. Directorate of University wide Courses, Landmark University, Omu-Aran. Pp.2-11.

xxxix. Osisanwo, W (2003) Introduction to discourse analysis and pragmatics. Ibadan: Alafas Nigeria Company.

xl. Otagburuagu, E.J. (2015) English language, literature and national transformation. A keynote address presented at the $31^{\text {st }}$ conference of the English Scholars association of Nigeria (ESAN) held at the Federal University, Lokoja, 27th October, 2015.

xli. Owolabi, D. (2016) Pedagogical considerations for effective second language English in non-native environments. Journal of English Scholars Association of Nigeria. 18,2: 135-144.

xlii. Peters, P. (2004)The Cambridge guide to English usage. Cambridge: Cambridge University Press.

xliii. Stubbs, M. (1995) Discourse analysis: The sociolinguistic analysis of natural language. Oxford: Blackwell. 